\title{
INTERNATIONAL AESTHETICS AND ITS CONGRESSES
}

\section{Aleš Erjavec}

Slovenian Academy of Sciences and Arts

ales.erjavec@zrc-sazu.si

\section{A $B$ S $S$ T}

In recent decades international congresses of aesthetics have been and remain the most visible and influential aesthetics gatherings in the world. At such congresses their participants strengthen their identification with aesthetics and separate themselves from it at the same time: they cover the broad and undefined territory called 'theory'. By taking place in different geographical and thereby specific cultural and historical localities, aesthetics congresses not only bring together foreign participants, but also bring domestic audiences into contact with global authors, themes, issues and methods. The themes, issues and methods mediated through art and philosophy help make aesthetics a relevant theoretic activity. This is true concerning some noteworthy recent events: the rise and decline of postmodernism; the reintegration of the former Eastern Europe into global culture; and a similar but also profoundly different transformation of aesthetics in China, where a new revival of aesthetics, often with Chinese colours, is intensively present. These are, I would claim, three historic events that have emerged in aesthetics over the past three decades. They are still with us today and thus remain crucial to understanding our reality. Exceptions exist too, proving that novel philosophical aesthetic theories are rare today but not impossible; such as that of Jacques Rancière, for example. These will be some of the main issues of this paper. 
In recent decades international congresses of aesthetics have become the most visible and, I would argue, the most influential aesthetics gatherings in the world. Themes, issues and methods mediated through art and philosophy have made aesthetics not only a relevant but also a dynamic theoretic activity. It is through a mixture and combination of various usages of aesthetics that its recent or past terms and concepts are further gaining in importance. Through a series of events that took place in the last few decades "theory" has regained the ground which it held from the 1960s to the early1980s. This does not mean that at that early stage theory carried a more general impact than it did later or earlier, but that it became a breeding ground for a specific type of discourse - one that ceased being erected on philosophy as a particular type of theory. This historical process has seen the rise and decline of postmodernism; the reintegration of the former Eastern Europe into global culture; and a similar but also profoundly different transformation of aesthetics in China.

I first attended such a gathering in Dubrovnik in 1980 in the IX International Congress for Aesthetics (ICA), the predecessor of the International Congresses for Aesthetics. This was my first opportunity to meet a number of specialists whose work I have been familiar with and many of whom I have remained in regular contact over the decades. Taking a fresh look at the Dubrovnik congress, I recall being impressed by the number of analytic American philosophers and Soviet conservative Marxists who participated in it.

Since then, international congresses for aesthetics have taken place in Montreal, Nottingham, Madrid, Lahti, Ljubljana, Makuhari/Tokyo, Beijing, Ankara and Seoul, with each of them being different, depending on the local organisers, their cultural affinities, and the aestheticians and philosophers they viewed as important and relevant for their own aesthetic tradition. Americans and Russians continue to attend these events, with the latter in much smaller numbers than before.

From the start, it has to be noted that the International Association for Aesthetics (IAA) is certainly not the only aesthetic organisation. There is an International Association for Empirical Aesthetics, the European Society for Aesthetics and, especially, national societies that bring together art historians, psychologists and other professionals interested in research into art and aesthetics. It is these latter that form - I would claim - the backbone of the IAA. 
As noted above, one cause for the ever-changing aesthetics landscape, when viewed from the vantage point of international congresses, is its strong dependency on local cultural circumstances. Since art is its predominant subject in most parts of the world, this implies a strong link between aesthetics and local art and culture. This is also the way in which cultural events occur and are appreciated. In the former Soviet republics, aesthetics started to be regarded long ago in a similar vein as in western postmodernism. Some of the art from these countries emerged in the 1970s and 1980s and soon formed a specific politicised postmodern art.

Some of those who have in recent years and decades attended the ICA have encountered a paradox: while each new ICA resembles its predecessor, it at the same moment also profoundly differs from it, with this difference resting not only upon cultural characteristics but also upon the meaning and import of theory (or certain theory) within a particular congress venue.

Let me return to theory. This is how the term is explained in Wikipedia: 'A position or a system of ideas intended to explain something, especially one based on general principles independent of the thing to be explained.'

The ICA gatherings are different from most of the others due to the pronounced cultural specifics that are absent from the rest. It is thus fair to claim that in the case of aesthetics such differences arose from the cultural specificity of individual congress venues and their specific features. If and why theory is present at such venues rather than a combination of various specifics (historical, cultural, political, linguistic, philosophical, artistic, etc.) helps explain the relatively stable entity that we designate as specifically national, regional or international and global aesthetics congresses.

The tension between theory and aesthetics arose at a time when theory was still in the shadow of aesthetics, interpreted as a philosophical unfolding. It was viewed within philosophy of the phenomenological kind because it was regarded as a branch of philosophy - at that time there was simply nothing else yet there.

The first time in the previous century that theory especially vividly manifested itself was in the French theory of the 1960s. In contrast to France where art and aesthetics were tied to the notions of enlightenment and civilisation, the accent was put on culture in the English-speaking countries and Germany. The first began to relate to rigorous science and the latter to fiction. 
French discourse consisted of a variety of authors whose writing existed on different tracks, and thereof coincided only to a limited extent. Theory signified at the same time Marxism, Freudian psychoanalysis and the emergent structuralism. Perhaps the best-known and the most representative work with that title and content was the collection Théorie d'ensemble published in 1968, which brought together writings by Michel Foucault, Roland Barthes and Jacques Derrida. From the vantage point of the present it is easy to regard these three authors as related, still you will probably agree that these three thinkers also differ enormously. Foucault, Barthes and Derrida, while sharing a certain theory or theories did not really share a common philosophy (although they were about to make one). Only later, in the1970s, did these theories start to be regarded as philosophy - with philosophy now losing its previous characteristics and becoming more a mixture of discourses typical of the last few decades. An insightful observation was made by Michel Foucault in 1978 when he designated these types of intellectuals as 'founders of discursivity." This French theory, combined with the Frankfurt School, acquired a specific name in the English-speaking cultures, namely post-structuralism, in the 1980s and 1990s. Yet another name for this body of ideas was 'cultural theory', which Terry Eagleton in its prime age identified with Jacques Lacan, Julia Kristeva, Louis Althusser, and many others - such as Raymond Williams, Jurgen Habermas, and Fredric Jameson.

In the 1970s and 1980s in France such theory opposed philosophy, especially the phenomenological kind, such as Sartre's, Maurice Merleau-Ponty's, Mikel Dufrenne's ${ }^{2}$ and partly that of Martin Heidegger - philosophy that found its centres in the academic establishments - the kind that a French critic ironically called 'poetry' as opposed to authentic (theoretical) philosophy and science (the latter as opposed to 'ideology'). ${ }^{3}$ In another volume from the same time, namely the collection Qu'est-ce que le structuralisme?, ${ }^{4}$ Oswald Ducrot opposed ideology to theory. In that same epoch international aesthetics was firmly in the hands of phenomenology.

It was only with postmodernism in the early 1980s that international aesthetics consciously appropriated a theory that was not only more widely accepted but also contemporary. It was since then that international aesthetics could start to be plausibly called 'critical aesthetics'. To bring into its fold another contemporary body of theory, it had to embrace the Frankfurt School. 
In this framework theory usually functioned as an empty signifier that was often used but rarely defined or described. ${ }^{5}$ Another important author focusing on theory was Terry Eagleton, who in his book After Theory ${ }^{6}$ (2003) discovered a new need for theoretical rigour that would replace the previous and present relativism in values. In conjunction with critical aesthetics, his theory can be seen today as a dynamic fusion between the Frankfurt School of critical theory and the more traditional aesthetics (interpreted as philosophy of art, culture, and philosophy of sensibility). Many well-founded cases of criticism and the broad span of theories and art works that the Frankfurt School authors took into consideration come as a surprise even today. The other feature of critical theory was its conceptual and methodological variety, something that contemporary aesthetics often lacks. A related observation has to be made: despite the efforts of the Frankfurt authors to resist the usage of the term "aesthetics", such theories are today - although still with certain restrictions or limitations - understood as aesthetics. An illustration of such a position is that of Theodor Adorno, who designated his philosophy of art not as 'aesthetics' but as an 'aesthetic theory'. His reasons for this were clear as he said: 'Aesthetics presents philosophy with the bill for the fact that the academic system degraded it to being a mere specialisation'?

The ongoing globalisation and the transnational character of contemporary culture in the broad sense of the word (aesthetics therein included) and the withering away of national borders carries certain visible consequences for aesthetics at the international level. The ICA, for example, may be partly losing some of its previous relevance when it was essentially based on "national" societies for aesthetics, the role of which is, together with the nation-states, slowly diminishing in their national and international import.

The second and equally relevant fact is the geographical and cultural - not to say political - location of aesthetics.

Aesthetics travelled together with other "imperialist" cultural artifacts and influences, reaching continents, countries and cultures that before its arrival did not have equivalents to the western notion of aesthetics, which mostly praised a detached contemplation of art and beauty. The periods of enlightenment, romanticism, realism and modernism - the epochs of intense awareness of the import of aesthetics (and art) - coincided with the periods of colonisation and imperialism. The Kantian interpretation of art hegemonised the globe. Much of the change occurring first in the 1960s in Continental Europe and then along the American West Coast was due to structuralism, which started not as a theory or 
philosophy but as a method and "theory" and was able to "invade" all realms of the humanities and breach the epistemological borders between disciplines. It caused the disintegration of previously firmly divided and separated realms of the humanities and even of philosophy proper, for previously the latter only in some instances - in the critical theory of the Frankfurt School, for example intentionally and effectively overcame the disciplinary divisions. It still remains the main single influence on aesthetics and theory in that part of the world.

What emerged after the great, relatively homogenous philosophical currents of Marxism, existentialism and phenomenology of the first half of the previous century, was theoretic dedifferentiation of the former disciplines and were philosophical and theoretic "schools": groups of philosophers, who emerged around a referential philosophical figure, a theoretic tradition, etc. ${ }^{8}$ An example of this are the Lacanian psychoanalysts who emerged in Ljubljana in the 1980s or the Merleau-Pontyan existential phenomenology at Northwestern University in the USA. What structuralism accomplished in the 1960s was to transform philosophy into a theory of art and this one then into a much more empirical realm, whereby vague notions of "art" and "beauty" lost their previous relevance and their essentialist singularity. Barnett Newman's quip that: 'Aesthetics is for art what ornithology is for the birds'9 may perhaps still be applied, but aesthetics as such - or a part thereof - is being replaced by another kind of aesthetics. In the 1960s and 1970s, it did not yet have that designation but existed under a variety of terms, ranging from semiotics, deconstruction and Marxism to psychoanalysis. This emergent theory, which discarded most of its previous connections with traditional notions of art, so that the artist and the art work no longer existed under such a name, for the term was apparently contaminated by its metaphysical and essentialist foundations, signified a plethora of ways in which "theory" (once again) and philosophical scrutiny - signifying primarily a consequential and self-reflective approach - reached to the arts. As I have pointed out, in this new context aesthetics existed as a notion and not as a term, for the term was considered mostly to be a remnant of the past and something to be discarded. This aesthetics as the notion of aesthetics reached towards the arts, but to be productive in such a re-established contact it had to be plural to a much greater extent than aesthetics under modernism was. These aesthetics then went into different directions, arising from philosophical traditions and currents or mixing and combining them in what was termed as "theory" (and no longer as "philosophy" or philosophical aesthetics). Aesthetic approaches at one extreme defined art on the basis of borderline cases. A good example of this were the early writings of Arthur Danto wherein the author developed arguments for including the works of Marcel Duchamp or Andy Warhol within 
the perimeter called "art". The borderline cases such as these helped define art of a certain period and type in general. At the other extreme were authors such as Walter Benjamin, whose writings were posthumously recognised only in the 1980s with the advent of postmodernism. Under such recent circumstances, Benjamin's fragmentary discourse, devoted to Baudelaire and Kafka and from Baudelaire to the flâneur and the reproducibility of a work of art, not only met with approval but obviously touched upon issues which may have been irrelevant in the 1930s but gained strategic value in the 1980s. The mechanical reproducibility of art, the aura, the aestheticisation of politics, the presumably novel role of cinema with respect to its mass audience, photography, the changed mode of human fitted into the mould of traditional "aesthetics". These themes were all too fragmentary, lacked a homogenous and systematic frame and in all respects opposed the traditional academic discourse, of which aesthetics gave semblance of its integral part. In brief, it sounded very much like a certain kind of theory.

The most recent forms of aesthetics are those that either transcend the realm of art or reach into that of culture. Such discourse (such as for example Eagleton's book After Theory from 2001, mentioned above) no longer (or not only) speaks of aesthetics as a philosophy of art or of theory of culture, but of culture in relation to ethics and other implicitly cultural matters.

We need to research what Benjamin has called 'the [changed] mode of human sense perception'. ${ }^{10}$ If Hegel's epoch had romantic poetry as its artistic equivalent and as its 'cultural dominant', if Adorno's epoch had atonal music and expressionism, if Maurice Merleau-Ponty was the paradigmatic philosopher of modern painting, if Benjamin was a postmodern theorist of art avant la lettre and if Arthur Danto's early theory is the philosophical equivalent of conceptual art and a philosophical reflection thereof, what and who has this place today? Two centuries ago not only was art essentially dependent upon theory, but theory at that time also started to depend on art. It is this incessant dialectical interplay between theoretic reflection and artistic practice that today drives the tandem of art and theory.

Returning to aesthetic theory to reach a conclusion on the last few decades, I would say that any contemporary theory today refers partly to the writings and discourse of the1960s-70s, in other words to the discourse of structuralism and critical theory (or a combination thereof). In this respect the ICAs usually offer a highly representative insight into contemporary aesthetics and related theory. To designate the increasingly broad field of aesthetics and other 
discursive territories, we today frequently use a whole set of terms, unusual or as yet not assimilable, these ranging from aesthetics and aesthetic theory, to cultural theory, philosophy of art, theory of art, philosophy of culture, and so on. As I pointed out, an interesting term was and remains "theory" which lies at the intersection of structural and cultural approaches and at the intersection of various aspects of the aesthetic and the discursive domains (writing, textual production, and so on). Such theories emerge today as the designators of what not long ago was named philosophical aesthetics, on the one hand, and "signifying practice" on the other. In other words, it seems to me that today those kinds of philosophical aesthetics and theories that are capable of uniting or combining both have the possibility to create new "philosophies of theory and theories of philosophy". Arthur Danto, Jacques Ranciere, Slavoj Žižek and Boris Groys seem to me to belong to such thinkers. The hunger of artistic and cultural practice for such kinds of reflection almost guarantees the success of other persuasive newcomers to the scene.

I wanted to shed some light on the ICAs and the notion of theory as it is today either surviving the criticism of the past or being resurrected from this very same history. By taking place in different geographical and specific cultural and historical localities, aesthetic congresses (the ICAs) not only bring foreign participants to the doorstep of yet another region or continent, but also bring domestic aesthetic audiences into contact with global or international authors, authorities, themes, issues and methods. Moving between philosophy of art and culture and theory and aesthetics, these discourses are opening new vistas for the notions of aesthetics and theory in the twenty-first century. 
See Michel Foucault, "Qu'est-ce qu'un auteur," Bulletin, Societe francaise de Philosophie, 1xiv (1969).

See for example, Maryvonne Saison, Mikel Dufrenne, De l'esthétique au politique (Paris: Editions de la Sorbonne 2018). Qu'est-ce que le structuralisme? (Paris: Seuil 1968).

Numerous books of this kind exist. In this context, I had in mind the book by Mieke Bal and Inge E. Boer, The point of Theory (Amsterdam: Amsterdam University Press, 1994).

Terry Eagleton, After Theory (London: Penguin 2003).

On this see Aleš Erjavec, "Philosophy: National and International," Metaphilosophy, vol. 28, no. 4 (October 1997): 329-345.

Quoted in Arthur C. Danto, The Philosophical Disenfranchisement of Art (New York: Columbia University Press 1986), x.

Walter Benjamin, "The Work of Art in the Age of Mechanical Reproduction," Illuminations (New York: Schocken Books 1968), 222. 
Adorno, Theodor. Aesthetic Theory. Minneapolis: University of Minnesota Press, 1997.

Benjamin, Walter. "The Work of Art in the Age of Mechanical Reproduction." In Illuminations, 222. New York: Schocken Books 1968.

Bal, Mieke, and Inge E. Boer. The point of Theory. Amsterdam: Amsterdam University Press, 1994.

Danto, Arthur C. The Philosophical Disenfranchisement of Art. New York: Columbia University Press 1986.

Descombes, Vincent. Le meme et l'autre. Paris: Minuit, 1979.

Eagleton, Terry. After Theory. London: Penguin 2003.

Erjavec, Aleš. "Philosophy: National and International." Metaphilosophy, vol. 28, no. 4 (October 1997): 329-345.

Foucault, Michel. “Qu'est-ce qu'un auteur.” Bulletin, Societe francaise de Philosophie, 1xiv (1969).

Saison, Maryvonne. Mikel Dufrenne, De l'esthétique au politique. Paris: Editions de la Sorbonne 2018. 
Cilj moje diskusije je da istaknem karakter moderne i savremene estetike u odnosu na teoriju umetnosti, kroz dijagramsku refleksiju o binarnosti, razlikama i rekonstrukcijama dijalektike.

KLJUČNE REČI: UMENTIČKE ŠKOLE, MARKSIZAM, KRITIČKA TEORIJA, ANALITIČKA ESTETIKA, ISTORIJA UMETNOSTI, FENOMENOLOGIJA, STRUKTURALIZAM, POSTSTRUKTURALIZAM, SAVREMENA ESTETIKA I UMETNOST

\section{JEDNO ISLAMSKO NUMERIČKO TUMAČENJE SVETE SOFIJE U CARIGRADU}

\section{Vladimir Mako}

Ideje koje se odnose na estetičko mišljenje o arhitekturi tokom istorije su razvile brojna tumačenja o kulturnom i društvenom značaju građevina. Ova tumačenja su često oblikovana kao svet mogućeg postojanja posebnih značenja struktuiranih snagom čovekove imaginacije kojom dosežu nesvakidašnje nivoe kreativnog saznanja o tome šta arhitektura može suštinski odražavati.

U tom smislu rad istražuje jedan takav mogući svet značenja, predstavljenog u obliku numeričkog tumačenja arhitektonske strukture Svete Sofije u Carigradu. Pored svoje složene i hermenautičke prirode, analizirani dokument otkriva visoko prefinjeni nivo međuodnosa različitih kulturnih elemenata. Oni su povezani u celinu čija idealistička i poetska priroda, čini se da je zasnovana na kosmopolitanskom pristupu filozofiji, religiji, kao i ljudskoj sposobnosti razumevanja božanske suštine kreativnosti.

KLJUČNE REČI: ARHITEKTURA, ESTETIKA, BROJ, ISLAMSKA FILOZOFIJA, KOSMIČKA STRUKTURA

\section{MEDJUNARODNA ESTETIKA I KONGRESI NA TU TEMU}

\section{Aleš Erjavec}

Poslednjih decenija međunarodni kongresi na temu estetike su bili i ostaju najvidljiviji i najuticajniji estetski skupovi u svetu. Na tim kongresima učesnici jačaju svoju identifikaciju sa estetikom i istovremeno se odvajaju od nje: pokrivaju široku i nedefinisanu teritoriju zvanu "teorija". Održavajući se na različitim geografskim, a time i specifičnim kulturno-istorijskim lokalitetima, kongresi na temu estetike ne samo da okupljaju strane učesnike, već dovode i domaću publiku u kontakt sa globalnim autorima, temama, problemima i metodama. Teme, pitanja i metode se posmatraju kroz umetnost i filozofiju i pomažu da estetika postane relevantna teorijska aktivnost. To važi za neke zapažene nedavne događaje: uspon i pad postmodernizma; reintegracija bivše istočne Evrope u globalnu kulturu; i slična, ali takođe duboko drugačija transformacija estetike u Kini, gde je intenzivno prisutan novi preporod estetike, često sa kineskim bojama. To su, rekao bih, tri istorijska dogadjaja koja su se pojavila u estetici tokom poslednje tri decenije. Oni su i danas prisutni i tako ostaju presudni za razumevanje naše stvarnosti. Postoje i izuzeci koji dokazuju da su nove filozofske teorije estetike danas retke, ali nisu nemoguće; kao na primer teorija Žaka Ransijera. Ovo će biti neka od glavnih pitanja kojima će se baviti ovaj rad.

KLJUČNE REČI: MEDJUNARODNA ESTETIKA, MEDJUNARODNI KONGRESI O ESTETICI, TRANSFORMACIJA ESTETIKE, ŽAK RANSIJER, TEORIJE ESTETIKE 